\title{
Traditional Knowledge of Medicinal Plants Used in the Northeastern Part of Morocco
}

\author{
Mohamed Reda Kachmar (D, ${ }^{1}$ Hanae Naceiri Mrabti ${ }^{D},{ }^{2}$ Meryem Bellahmar, \\ Abdelilah Ouahbi, ${ }^{1}$ Zoubida Haloui, ${ }^{1}$ Khalid El Badaoui, ${ }^{1}$ Abdelhakim Bouyahya $\left(\mathbb{D},{ }^{3}\right.$ \\ and Said Chakir ${ }^{1}$ \\ ${ }^{1}$ Team of Medicinal and Aromatic Plants Valorisation and Environment, Environment and Health Laboratory, \\ Faculty of Sciences, Moulay Ismail University, P. O. Box 11201, Zitoune, Meknes, Morocco \\ ${ }^{2}$ Laboratory of Pharmacology and Toxicology, Bio Pharmaceutical and Toxicological Analysis Research Team, \\ Faculty of Medicine and Pharmacy, Mohammed V University, BP 6203, Rabat, Morocco \\ ${ }^{3}$ Laboratory of Human Pathologies Biology, Department of Biology, Faculty of Sciences, Genomic Center of Human Pathologies, \\ Faculty of Medicine and Pharmacy, Mohammed V University, Rabat, Morocco
}

Correspondence should be addressed to Abdelhakim Bouyahya; boyahyaa-90@hotmail.fr

Received 6 April 2021; Accepted 27 July 2021; Published 6 August 2021

Academic Editor: Abraham Wall Medrano

Copyright (C) 2021 Mohamed Reda Kachmar et al. This is an open access article distributed under the Creative Commons Attribution License, which permits unrestricted use, distribution, and reproduction in any medium, provided the original work is properly cited.

\begin{abstract}
The knowledge of the plants that are used may provide insight on their properties for further exploration. This study aimed to identify and collect data about medicinal plants used in traditional medicine by the population of the provincial region of Taza, Morocco. An ethnobotanical survey was carried out among 200 informants, competent villagers, herbalists, and traditional healers from the provincial region of Taza city through direct interviews using a structured questionnaire. The survey reported 55 plant species belonging to 28 families used in the folk medicine. Informants' results showed that the most frequently used plants were Origanum compactum, Mentha pulegium, Rosmarinus officinalis L., Aloysia citrodora, Calamintha officinalis Moench, and Artemisia herba-alba Asso., with a relative frequency of citation of $76 \%, 72 \%, 60 \%, 42 \%, 40 \%$, and 30\%, respectively. Moreover, in this study, the Lamiaceae family was the most commonly reported plant family, and the leaves were the most frequently used parts of the plants; otherwise, decoction and infusion were the most used modes in the preparation of remedies from medicinal plants in the traditional medicine. The sociodemographic characteristics showed that women use medicinal plants slightly more than men, the illiterate people use the medicinal plant the most, and old people have more information about the medicinal plants than the new generations. The region of Taza of Morocco has an important floristic biodiversity of medicinal plants which are used in traditional medicine practice. This result provides a good database for pharmacological screening in the search for new plants that can contain new bioactive molecules that can be used as a bioactive ingredient of medicament or as a biological alternative in pharmacology.
\end{abstract}

\section{Introduction}

For a long time, plants have played a very important role in the daily lives of human life [1]. Herbal medicines have traditionally been used because of several benefits; they are affordable and easily accessible, and there is no evidence of resistance to whole plant extracts or of effectiveness [2]. This sort of traditional medicinal knowledge has been regularly practiced in homes and is transferred from generation to generation with the passage of time [3]. Nowadays, the use of plants as a way of treatment is still very important for many rural and urban Moroccans [4]. In recent decades, scientific studies have increasingly focused on plants used in traditional medicine to treat various diseases through botanical surveys and laboratory biological tests on animal models to discover certain species with medicinal properties that may 
replace certain chemical drugs with side effects $[5,6]$. Morocco is a Mediterranean country which is crisscrossed from east to west and from southwest to northeast by four mountain ranges, the Rif, the Middle Atlas, the High Atlas, and the Anti-Atlas; his position between two seas and a vast desert results in a complete range of Mediterranean bioclimates. This varied climate provides habitat for rich and varied flora: more than 4200 spontaneous species and some 1500 introduced species have been catalogued $[1,7,8]$. The region of Taza is located between the mountain ranges of the Rif and the Middle Atlas; its climate is characterized by dry and very hot summer and cold, precipitating, and partly snowy winter. During the year, the temperature generally ranges from $5^{\circ} \mathrm{C}$ to $36^{\circ} \mathrm{C}$ and is rarely below $2^{\circ} \mathrm{C}$ or above $41^{\circ} \mathrm{C}$. This climate makes this region very rich in plant biodiversity and in wide varieties of indigenous medicinal plants used by the local population in the folk medicine. To the best of our knowledge, few works in the literature were interested in this region. Thus, the aim of this work was to collect information about plant species used in folk medicine by the traditional healers and local population of this region to treat diseases and human pathologies. For these reasons, the current survey was conducted in the provincial area of Taza of Morocco (northeastern Morocco).

\section{Materials and Methods}

2.1. Study Area. Taza city is administratively part of the Region of Fez-Meknes, it is located in the northeast of Morocco, and it is located in a mountain pass where the mountain range of the Rif and that of the Middle Atlas meet (Figure 1). Taza province is bordered to the north by the province of Al Hoceima, to the northeast by the province of Nador, to the east by the province of Taourirt, to the south by that of Boulemane, and to the west by the province of Taounate and that of Sefrou (latitude: $34^{\circ} 13^{\prime} 00^{\prime \prime} \mathrm{N}$, longitude: $4^{\circ} 01^{\prime} 00^{\prime \prime} \mathrm{W}$, and altitude: $550 \mathrm{~m}$ ). This city covers an area of $37 \mathrm{~km}^{2}$ with a population of 148,456 inhabitants in 2014 .

2.2. Ethnobotanical Survey. The first interview was conducted with the informants, giving them a brief explanation of the objective of the study and the importance of the information they were going to provide in order to sensitize them to participate in this study. In total, 200 people were interviewed directly between May and August 2016 through ethnobotanical surveys in different localities, cities, towns, villages, and douars in the province of Taza.

During the interviews, structured questionnaires were used for data documentation, 20 questionnaires for each zone, and the selected zones were dispersed between the city of Taza, the villages, and the douars of the Rif Mountains and the Middle Atlas belonging administratively to the province of Taza. Each questionnaire consisted of two parts. The first part concerns demographic information such as sex, age, educational level, source of information, and the profession of the participants, while the second part has informative questions on local names of plant species, mode preparation (decoction, maceration, infusion, etc.), the plant part used (stems, roots, leaves, seeds, aerial part, etc.), the method of administration, and the diseases treated by the plants mentioned by the informant. In each interview, the names of the plants were recorded in Moroccan Arabic when they were mentioned.

The botanical materials of 55 plant species were collected from the informants and kept in special glass frames; they were later identified by Pr. Abdelilah Rahou (Faculty of Sciences, Moulay Ismail University, Meknès). The confirmation was carried out by Dr. Mohamed Reda Kachmar using means of the literature.

These samples of plant materials were given herbarium specimen codes, and the voucher plant samples were kept in the Herbarium of the Botany Department of the Scientific Institute of Rabat, Morocco. The complete floristic list was established after the identification and verification of the samples; the identification process was realized using the following references: Moroccan Medicinal and Aromatic Plants [9], Vascular Flora of Morocco [10], Practical Flora of Morocco [10], and Traditional Moroccan Pharmacopoeia [11]. The taxonomy was confirmed on the basis of data available on the International Plant Names Index website: https://www.ipni.org/.

\subsection{Ethnopharmacological Parameter Analysis}

2.3.1. Relative Frequency of Citation. On the basis of the local therapeutic importance of each plant species, the relative frequency of citation (RFC) was calculated according to the following formula [12]:

$$
\mathrm{RFC}=\frac{\mathrm{FC}}{N},
$$

where FC is the number of participants who mentioned the use of a plant species and $N$ is the total number of participants.

2.4. Statistical Analysis. The results obtained were processed and analysed using Excel 2010 software.

\section{Results}

3.1. Sociodemographic Characteristics. A total of 200 participants comprising herbalists, competent villagers, traditional healers, and normal people from Taza city, including 114 women (57\%) and 86 men (43\%), were interviewed. Their average age was 52 years with a minimum of 19 years and a maximum of 85 years. The majority of the informants belonged to the rural area (90\%), and $61 \%$ were illiterate. The majority of participants received their education about herbal medicine from herbalists (54\%), while the rest learned from their older family members or from other people (Table 1).

\subsection{Medicinal Plants}

3.2.1. Medicinal Plants Used by the Informants in the Treatment of Various Diseases. The survey reached 56 plant 


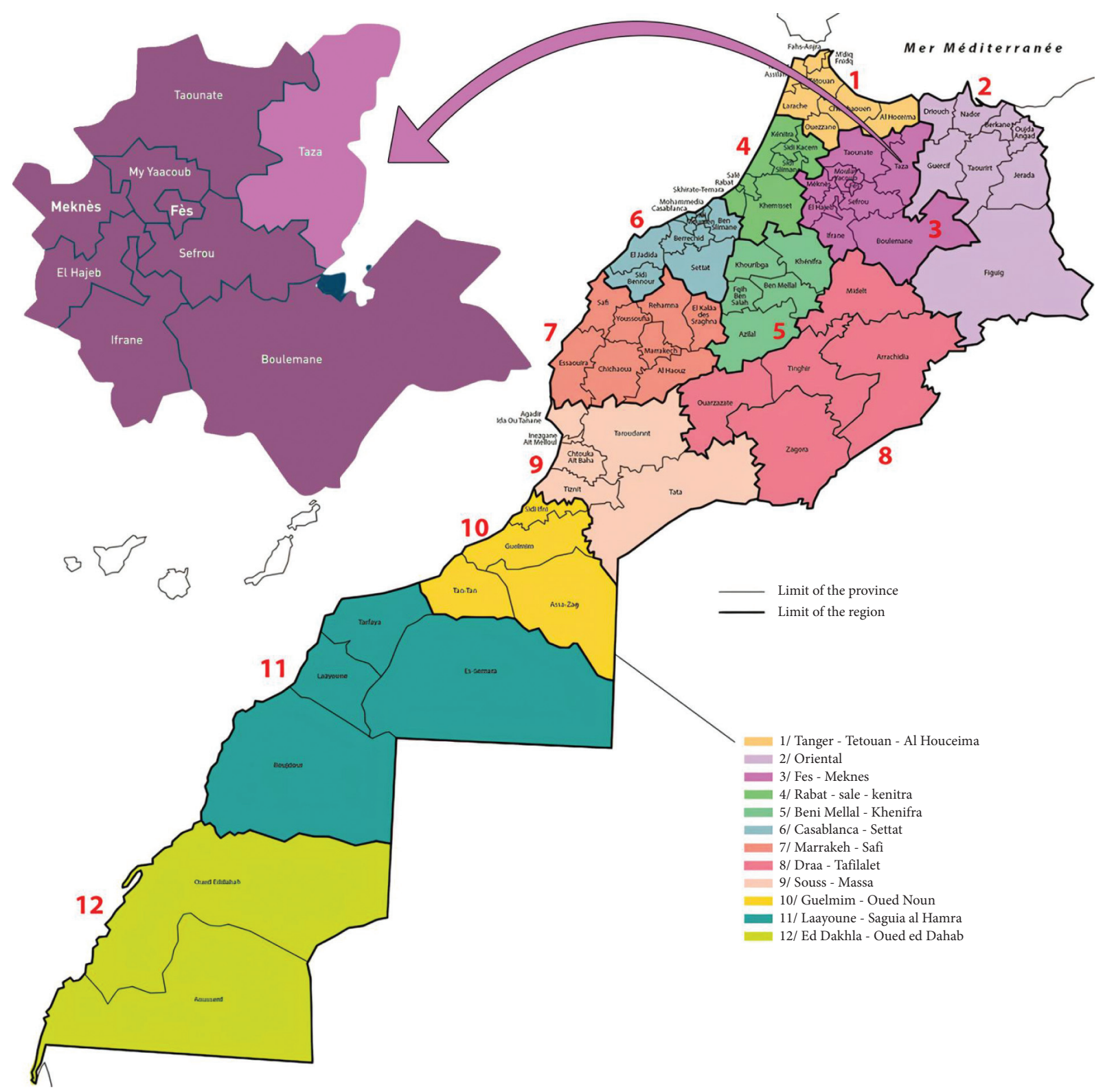

Figure 1: Map of the studied area (northeastern part of Morocco) (source: institutional website of the High Commission for Planning, Kingdom of Morocco, https://www.hcp.ma/region-fes/index.php?start=44).

species used in the treatment of various diseases by the participants in the Taza region. The most used species were Origanum compactum with the highest RFC ratio (76\%), followed by Mentha pulegium, Rosmarinus officinalis L., Aloysia citrodora, Calamintha officinalis Moench, and Artemisia herba-alba Asso., with the RFC value of $72 \%, 60 \%$, $42 \%, 40 \%$, and $30 \%$, respectively (Table 2). The images of the plants with the highest RFC values are shown in Figure 2.

Plants were grouped into 28 families; this census also shows different routes of administration of the drugs, the preparation methods, and the part of the plants used in the traditional medicine as presented in Table 1 . The most presented families were Lamiaceae (14 species), Apiaceae (6 species), Asteraceae (5 species), and Myrtaceae (3 species) followed by Cupressaceae, Lauraceae, and Zingiberaceae ( 2 species). All other families were presented by one species as shown in Figure 3.

3.3. Used Parts, Methods of Preparation, and Modes of Administration. Results obtained in this study showed that leaves were the most used part of the plants $(57.35 \%)$ followed by the stems (13.23\%), seeds (11.76\%), roots $(7.35 \%)$, flowers (5.88\%), fruits (2.94\%), and barks (1.47\%) (Figure 4). Our survey also showed that decoction and infusion were the most used methods of preparation with frequencies of $29.11 \%$ and $27.84 \%$, respectively, followed by the raw form (20.25\%), powder form (17.72\%), fumigation (3.79\%), and vegetable oil (1.26\%) (Figure 5). Oral administration of the drugs had the highest frequency $(70 \%)$, while the other 
TABle 1: Sociodemographic characteristics of the respondents.

\begin{tabular}{|c|c|c|}
\hline Characteristics & Number of informants $(n)$ & Frequency (\%) \\
\hline \multicolumn{3}{|l|}{ Ages (years) } \\
\hline $18-30$ & 64 & 32 \\
\hline $30-50$ & 96 & 48 \\
\hline$>50$ & 40 & 20 \\
\hline Total & 200 & 100 \\
\hline \multicolumn{3}{|l|}{ Gender } \\
\hline Male & 86 & 43 \\
\hline Female & 114 & 57 \\
\hline Total & 200 & 100 \\
\hline \multicolumn{3}{|l|}{ Education } \\
\hline Illiterate & 122 & 61 \\
\hline Primary school & 26 & 13 \\
\hline Secondary school & 18 & 9 \\
\hline High school & 10 & 5 \\
\hline University & 24 & 12 \\
\hline Total & 200 & 100 \\
\hline \multicolumn{3}{|l|}{ Profession } \\
\hline Sans & 38 & 19 \\
\hline Peasant & 40 & 20 \\
\hline Housewife & 74 & 37 \\
\hline Herbalist & 12 & 6 \\
\hline Official & 30 & 15 \\
\hline Others & 6 & 3 \\
\hline Total & 200 & 100 \\
\hline \multicolumn{3}{|l|}{ Origin of knowledge } \\
\hline Herbalist & 108 & 54 \\
\hline Popular culture & 46 & 23 \\
\hline Family heritage & 32 & 16 \\
\hline Others & 14 & 7 \\
\hline Total & 200 & 100 \\
\hline
\end{tabular}

administration modes (brushing, rinsing, massage, and inhalation) presented the rest 30\% (Figure 6).

\section{Discussion}

The main goal of this study is to identify the medicinal plants used in the province of Taza city. This region has an important and diversified heritage of aromatic and medicinal plants widely used in traditional medicine by the local population. This richness is also reflected by broad culture in phytotherapy and phytopharmacology among the selected informants, particularly herbalists and traditional healers.

Sociodemographic results showed that the age of all participants was between 20 and 86 years, and the most presented group of the informants having the age between 30 and 50 years (48\%). The result also showed that females use medicinal plants a little bit more than males. Our results confirm those obtained by other ethnobotanical studies made in other regions in Morocco [7, 128]. This must be due to that women are in charge of drying, stocking of medicinal plants, and preparing recipes for the care of family members.

Interviews showed that older people are particularly competent than the young generation and had a greater knowledge of the uses of medicinal plants for the cure of various diseases; similar results were observed by other studies [30, 129]. However, this finding did not exclude other age groups with valuable knowledge about herbal remedies. In fact, older people are expected to provide more reliable information because they hold more ancestral knowledge transmitted orally. The transmission of this valuable knowledge and medicinal recipes from the old to the new generation is not always assured and is now in decline [129].

In this study, women were the most presented (57\%) than men $(43 \%)$. These results agree with those of a previous ethnobotanical study done in the province of Tata, Souss-Massa region in Morocco [19]. This study was led in the southeast region of Morocco, while our study was conducted in the northeast region of Morocco; these two regions differ by their geographical locations and their climatic zones and consequently a difference in their plant biodiversity, which obviously affects the choice of the plant's species used in traditional medicine. Therefore, our survey showed that the most used plants in the Taza region were Origanum compactum, Mentha pulegium, Rosmarinus officinalis, Aloysia citrodora, Calamintha officinalis Moench, and Artemisia herba-alba Asso., while Artemisia huguetii, Mentha pulegium, Trigonella 


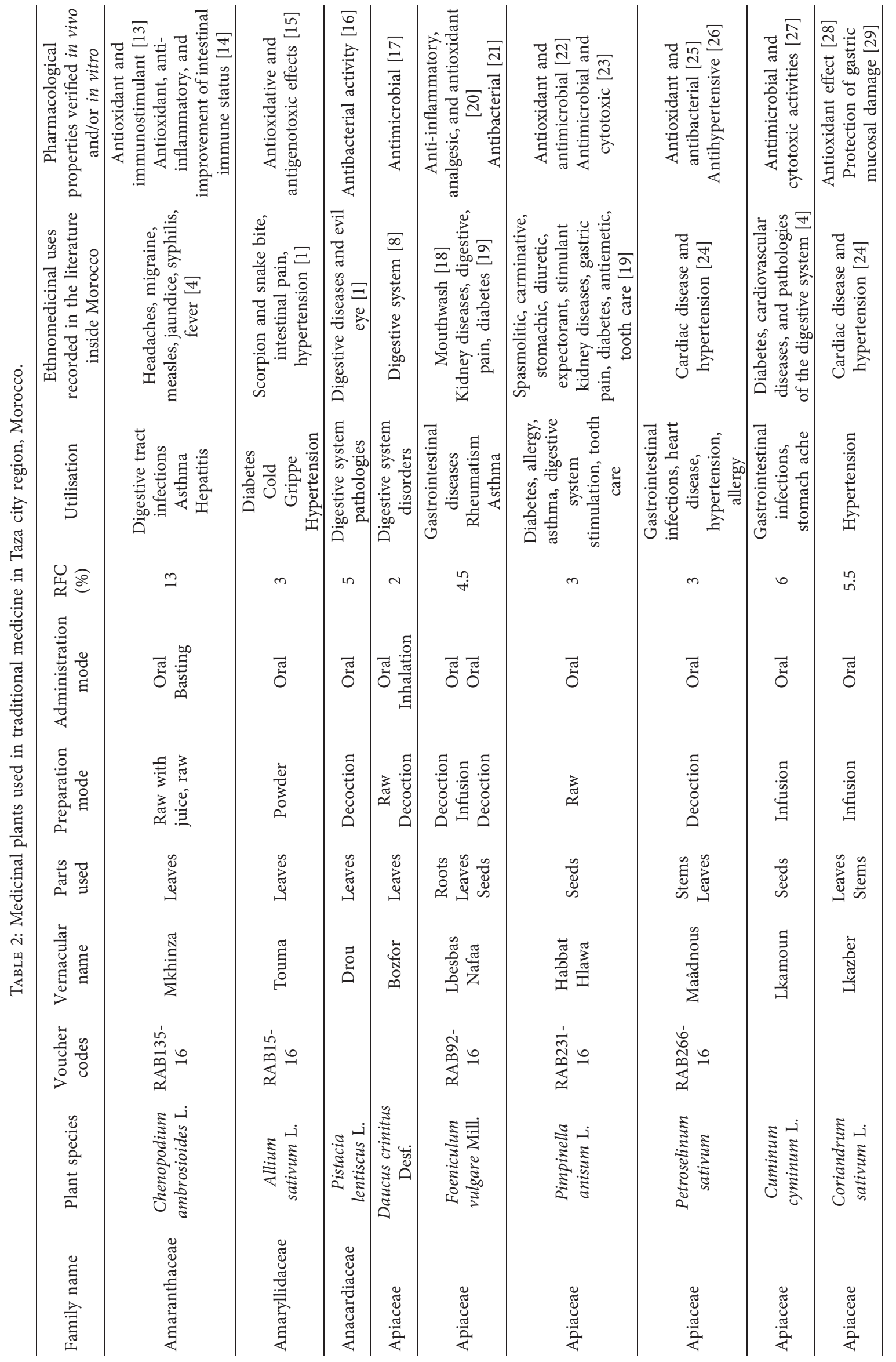




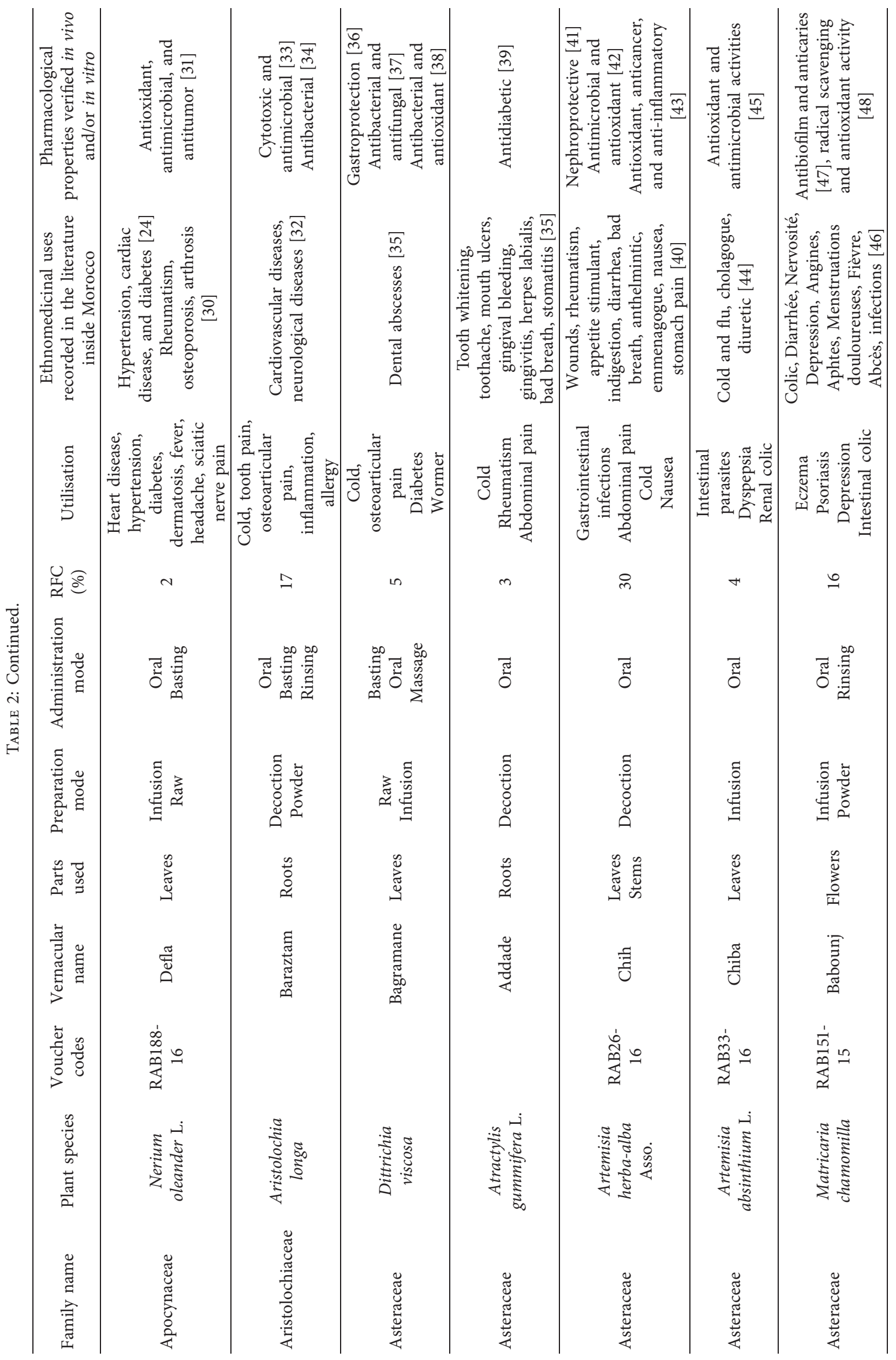




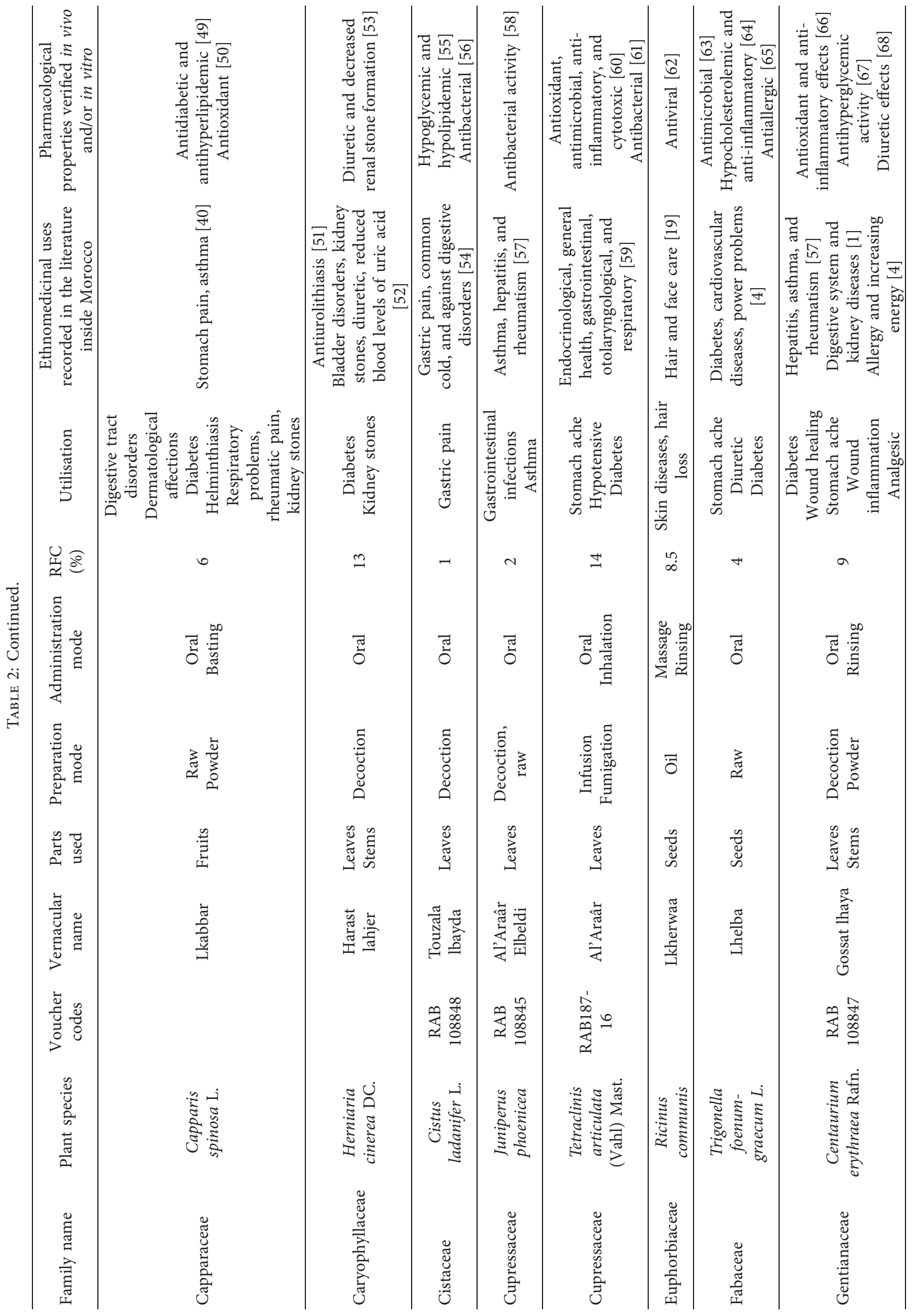




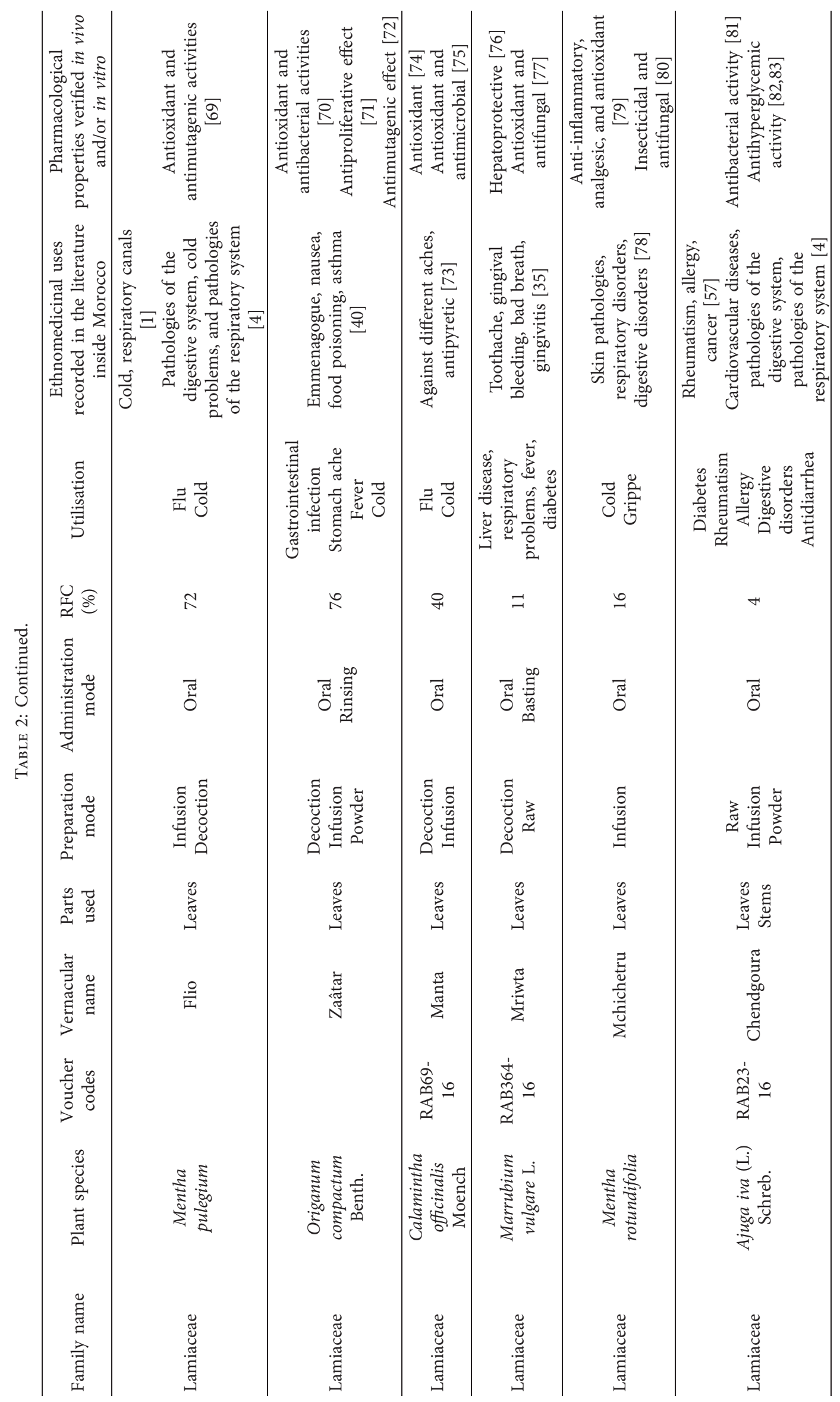




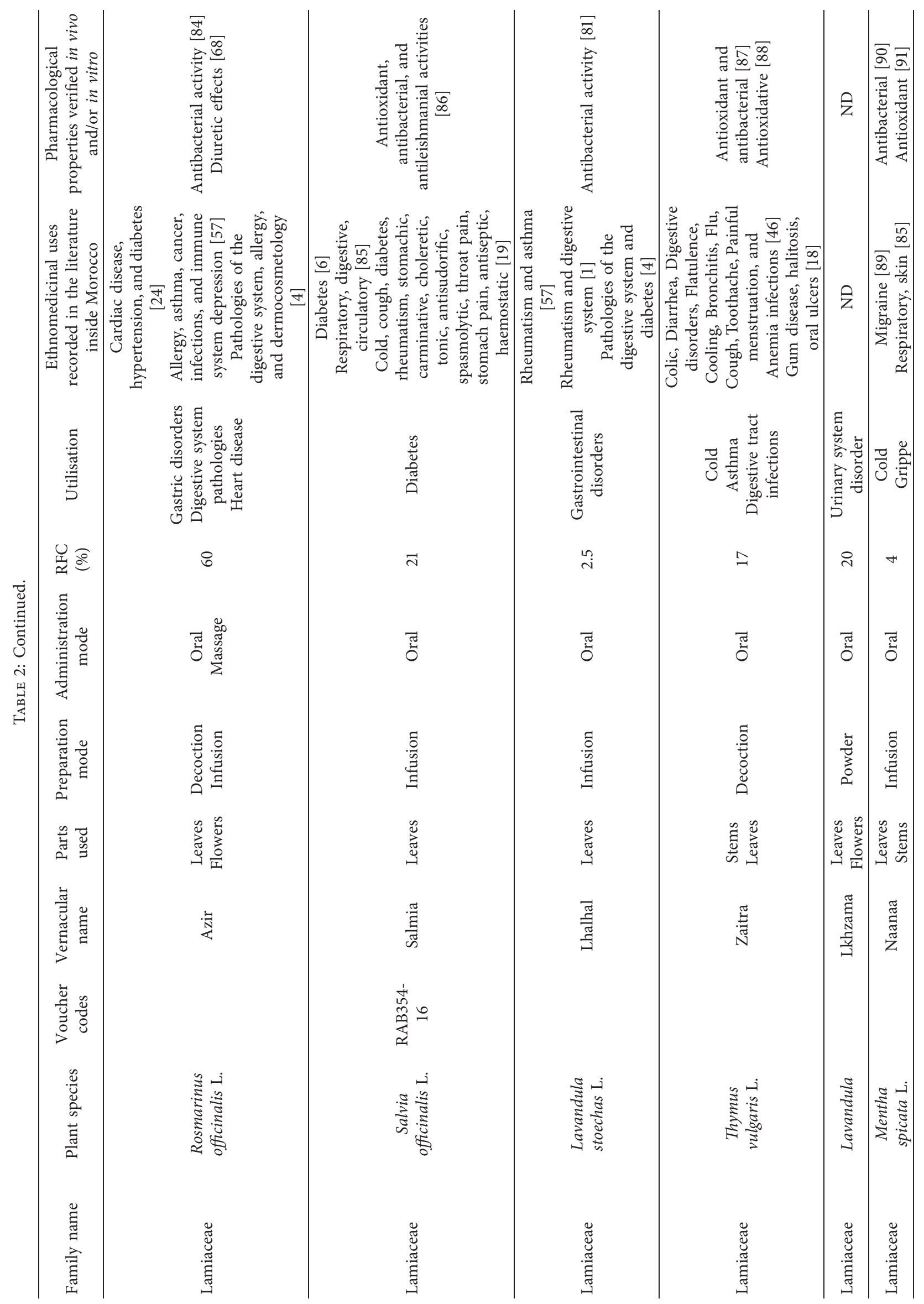




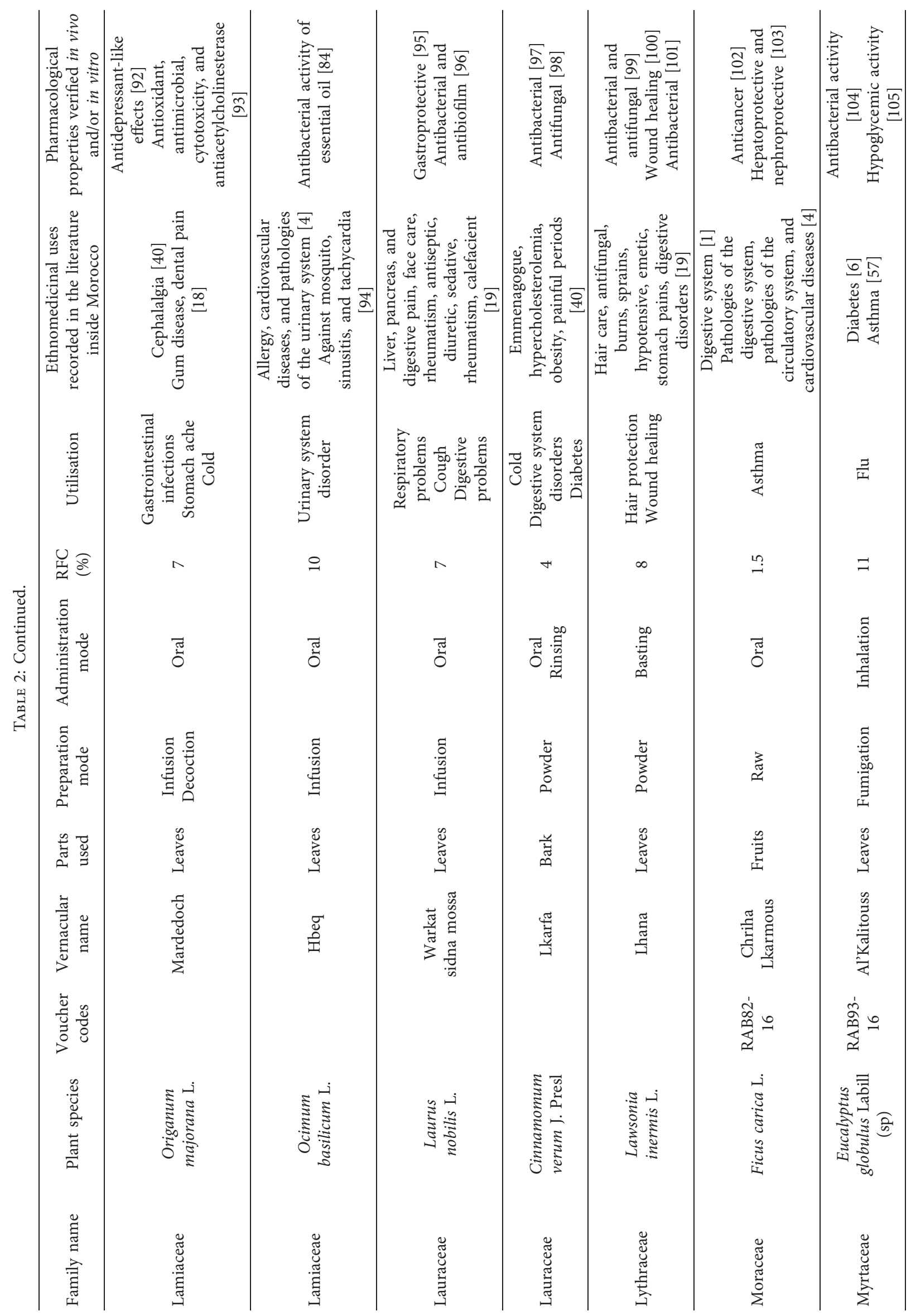




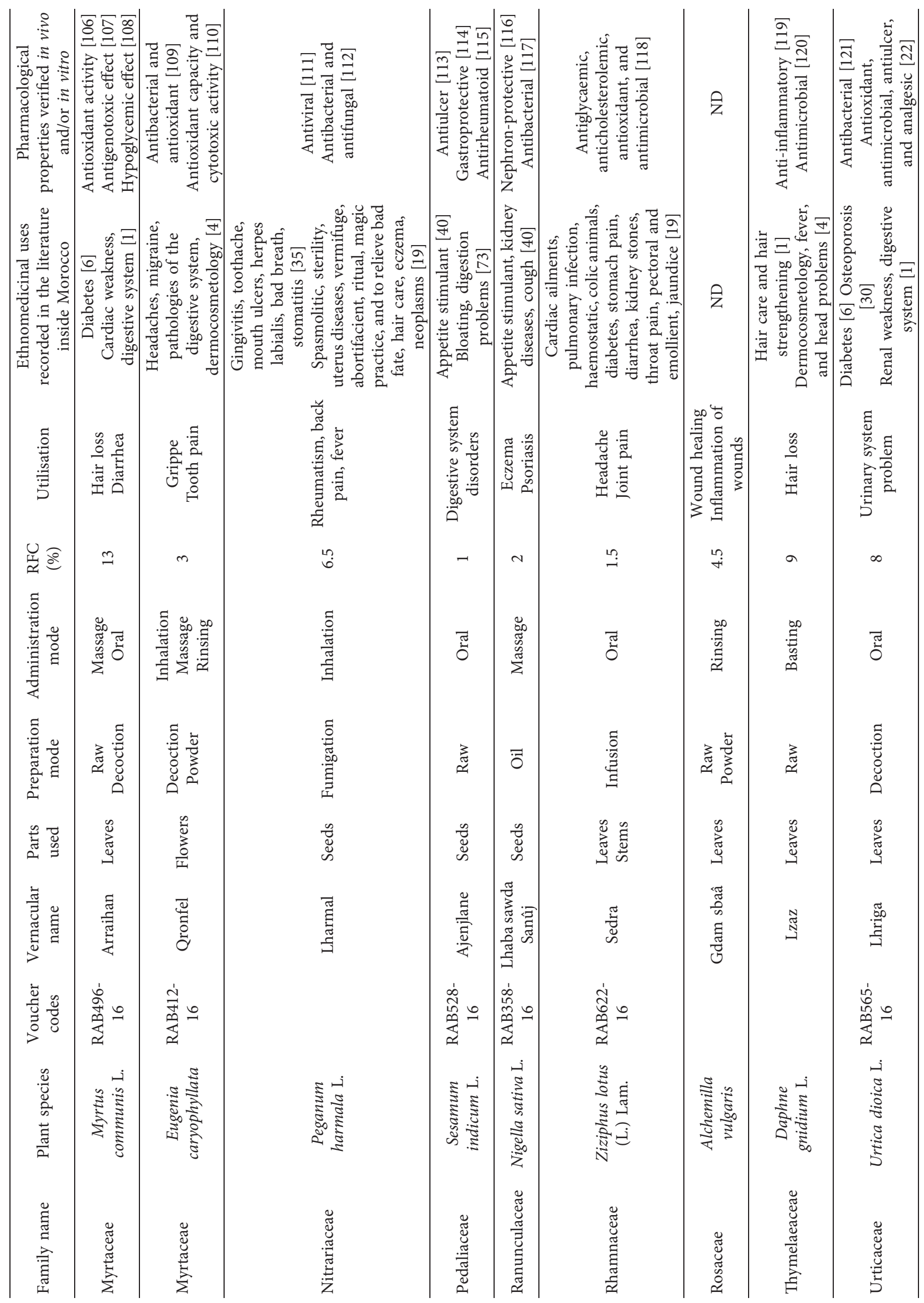




\begin{tabular}{|c|c|c|c|}
\hline 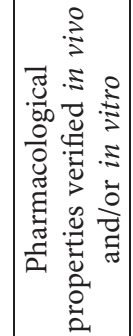 & 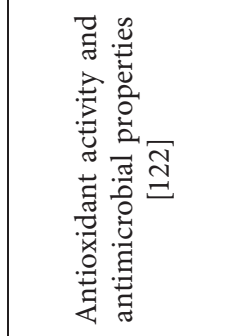 & 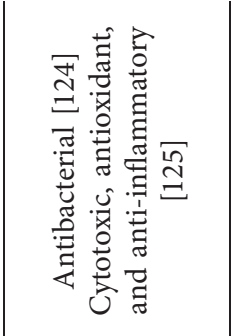 & 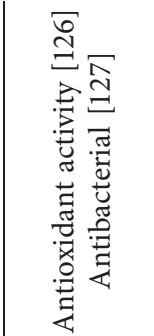 \\
\hline 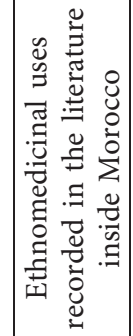 & 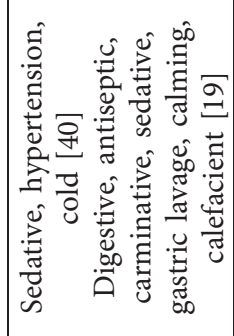 & 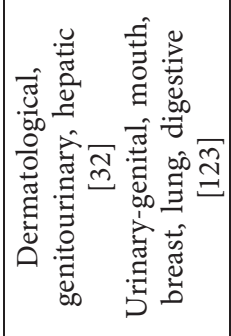 & 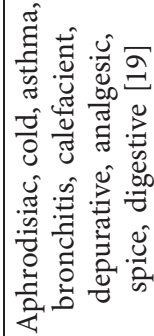 \\
\hline 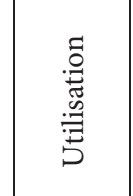 & 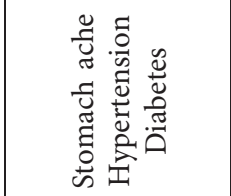 & 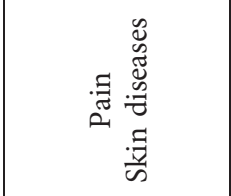 & $\begin{array}{l}\text { है } \\
\overline{0} \\
0\end{array}$ \\
\hline 焉 & F & - & $m$ \\
\hline 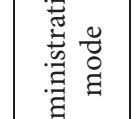 & 苟 & 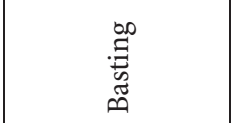 & 苟 \\
\hline 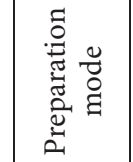 & 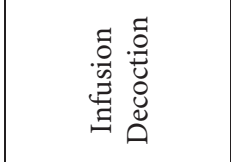 & 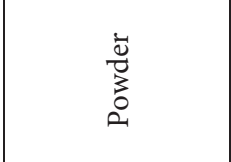 & 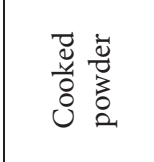 \\
\hline 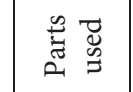 & 岕 & 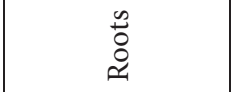 & 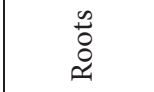 \\
\hline 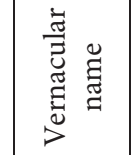 & 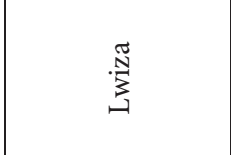 & 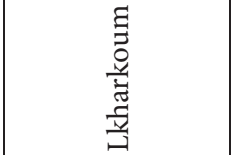 & 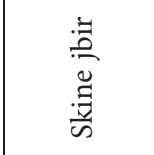 \\
\hline 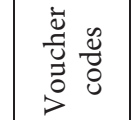 & & & \\
\hline 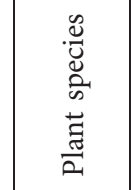 & 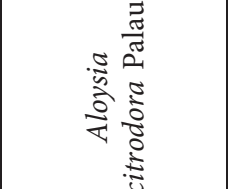 & 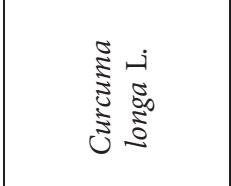 & 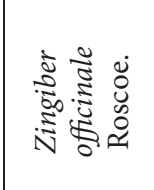 \\
\hline 离 & 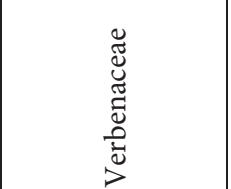 & 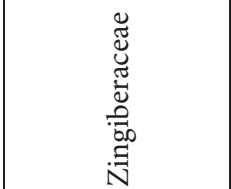 & 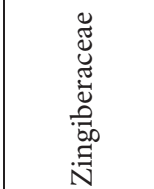 \\
\hline
\end{tabular}



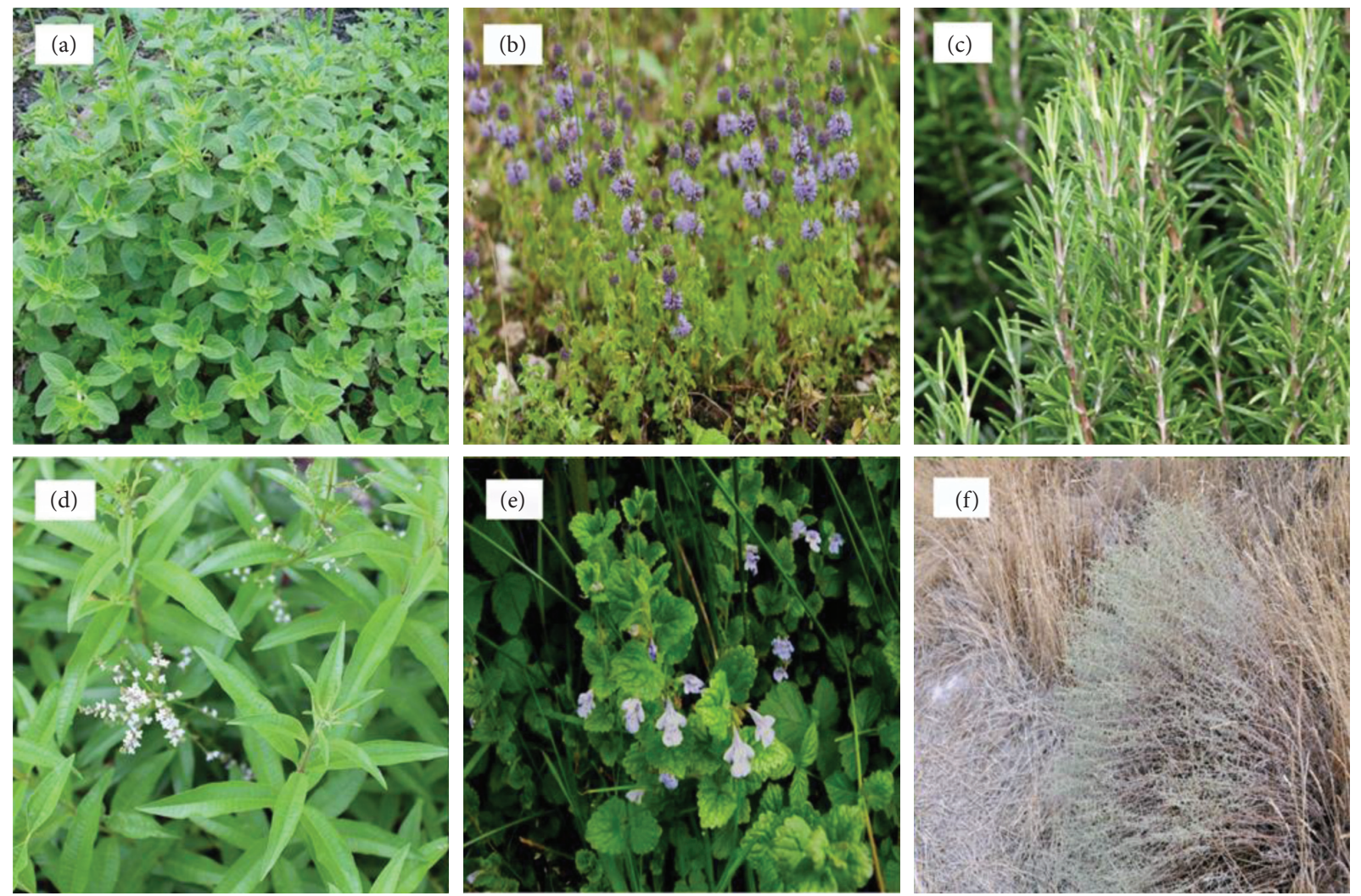

Figure 2: The pictures of (a) Origanum compactum, (b) Mentha pulegium, (c) Rosmarinus officinalis L., (d) Aloysia citrodora, (e) Calamintha officinalis Moench, and (f) Artemisia herba-alba Asso.

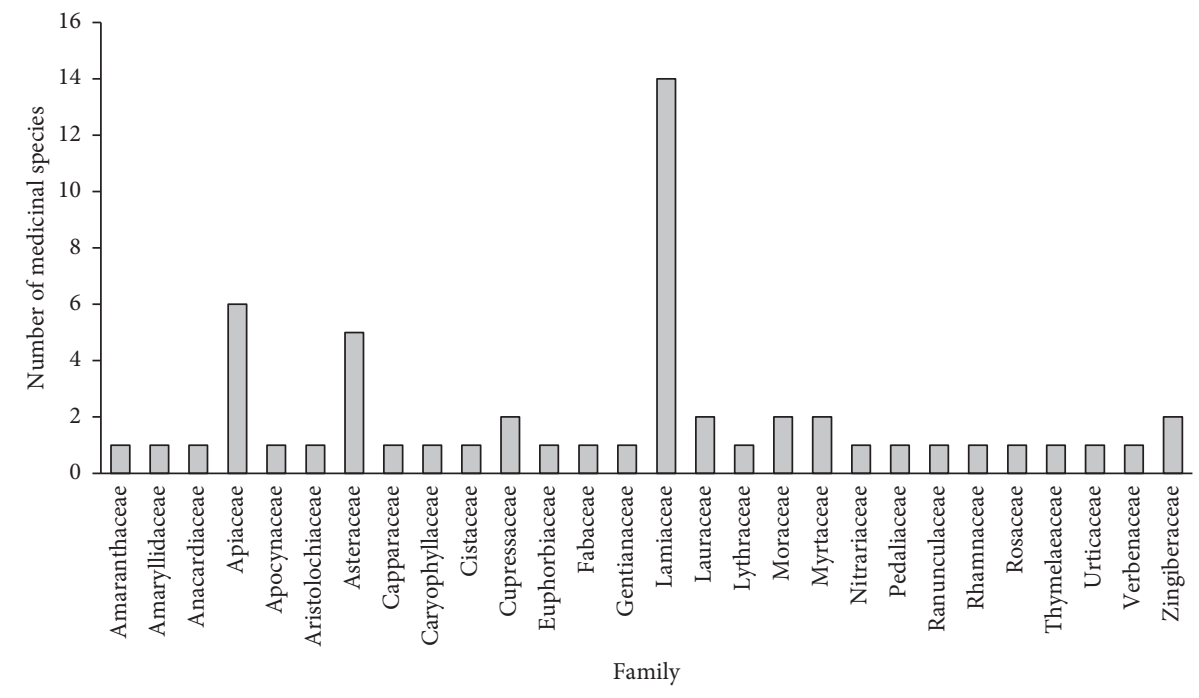

Figure 3: Number of species in each family mentioned by the respondents.

foenum-graecum, Mentha suaveolens, Lavandula mairei, and Nigella sativa were the most cited for their use in the traditional medicine in the study [19].

Results showed that $61 \%$ of the informants were illiterate, and their age was older than 40 years. These results are in agreement with other ethnobotanical studies carried out in Morocco [130] and Algeria [131]. The use of medicinal plants in traditional medicine is more widespread among illiterate people. These results are confirmed by other studies, which have shown that people with a lower level of education have more expertise in the uses of plants in traditional medicine $[132,133]$. On the contrary, the results of this survey indicate the predominance of some plant families such as the Lamiaceae, the Apiaceae, and the Asteraceae. The 


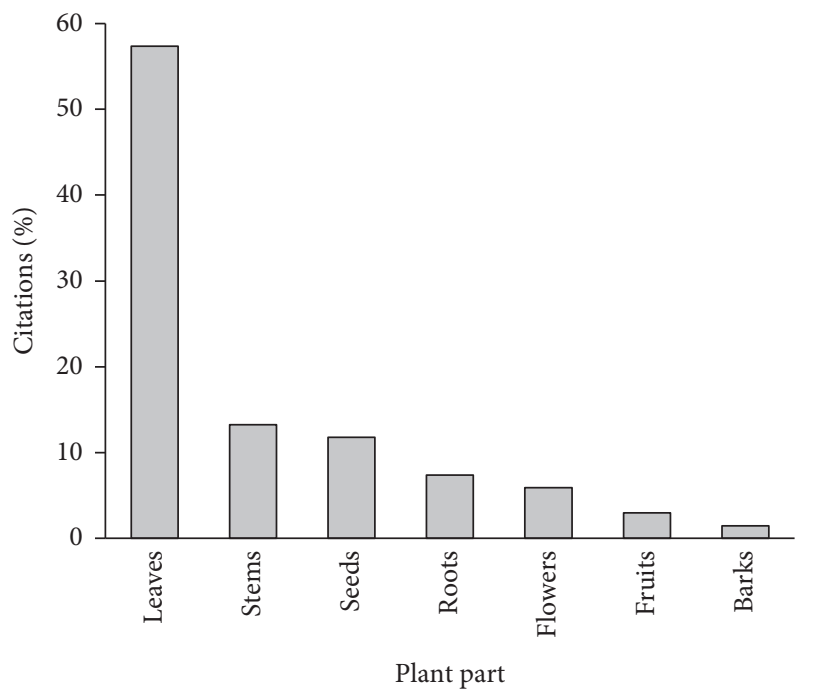

Figure 4: Frequency of different parts used.

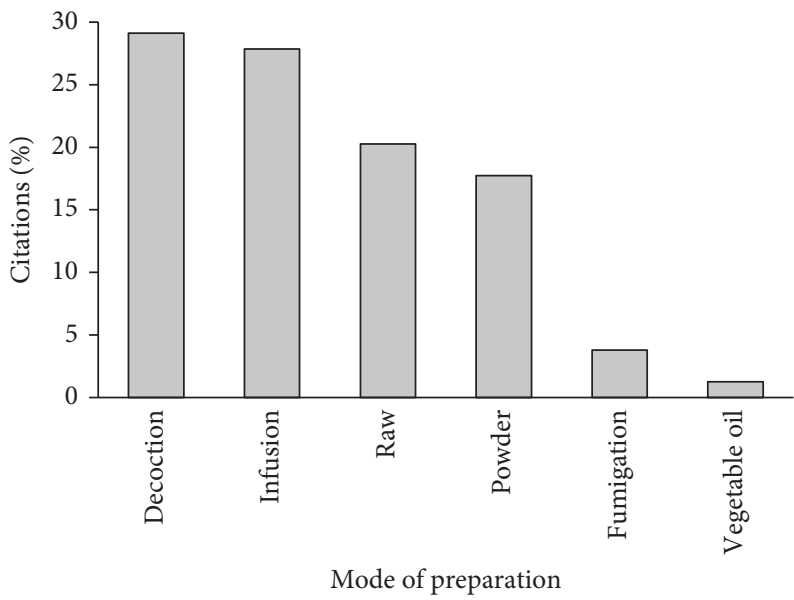

Figure 5: Frequency of different preparation methods.

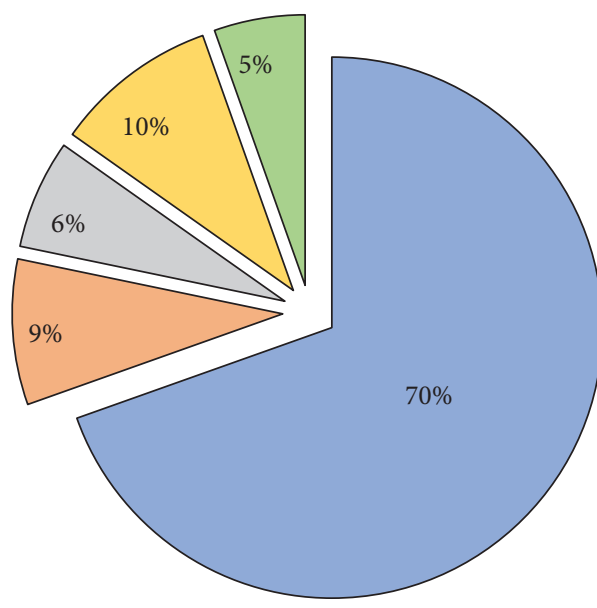
$\square$ Oral
$\square$ Brushing
$\square$ Rinsing
$\square$ Massage
$\square$ Inhalation

Figure 6: Frequency of the administration mode. 
predominance of these families has already been observed in a study carried out in another African country [134] and another study carried out in southeast Morocco [19]. Furthermore, the most used species by the population of Taza province were Origanum compactum with the highest RFC (76\%), followed by Mentha pulegium, Rosmarinus officinalis, Aloysia citrodora Palau, Calamintha officinalis Moench, and Artemisia herba-alba Asso., with RFC values of $72 \%, 60 \%$, $42 \%, 40 \%$, and $30 \%$, respectively. The medicinal properties that these plants have were experimentally proven by several studies carried out in vivo and/or in vitro by [135-141]. The plants used mainly by the population of the Taza region are almost the same as those previously mentioned in Morocco $[4,7]$ and in Algeria [142].

The use of leaves in traditional medicine could be attributed to their availability, the simplicity of their harvest, and their richness in therapeutic substances [143]. On the contrary, decoction was the most used method of preparing medicinal plants (29.11\%) followed by infusion (27.84\%), the raw form $(20.25 \%)$, the powder form (17.72\%), fumigation (3.79\%), and the vegetable oil form (1.26\%). This observation is in agreement with other ethnobotanical studies [57], which indicate that the recipes were essentially prepared by decoction, about $67 \%$ of herbal preparations were in the liquid form, and water was the solvent of choice in the preparation of herbal recipes because it is abundant and easy to access. The vast majority of remedies were taken orally (70\%); similar results have been obtained in other studies $[7,57]$.

\section{Conclusion}

This study showed that Taza region has a rich and varied patrimony of medicinal plant species used in the folk medicine to treat different diseases. In fact, the traditional recipes based on those plants must be validated and grouped into databases to become as a source for alternative therapeutic compounds, and their use must be conducted by safety and efficacy data, especially for herbalists and traditional healers. Nonetheless, chemical, pharmacological, and toxicological investigations in the medicinal plant area are required to determine and confirm their chemical composition and clinical uses to standardize their correct therapeutic doses.

\section{Data Availability}

The data used to support the findings of this study are included within the article.

\section{Conflicts of Interest}

The authors declare that they have no conflicts of interest.

\section{References}

[1] J. El-hilaly, M. Hmammouchi, and B. Lyoussi, "Ethnobotanical studies and economic evaluation of medicinal plants in Taounate province (Northern Morocco)," Journal of Ethnopharmacology, vol. 86, no. 2-3, pp. 149-158, 2003.
[2] M. Barkaoui, A. Katiri, H. Boubaker, and F. Msanda, "Ethnobotanical survey of medicinal plants used in the traditional treatment of diabetes in Chtouka Ait Baha and Tiznit (Western Anti-Atlas), Morocco," Journal of Ethnopharmacology, vol. 198, 2017.

[3] M. Ullah, M. U. Khan, A. Mahmood et al., "An ethnobotanical survey of indigenous medicinal plants in Wana district south Waziristan agency, Pakistan," Journal of Ethnopharmacology, vol. 150, no. 3, pp. 918-924, 2013.

[4] J. Fakchich and M. Elachouri, "Ethnobotanical survey of medicinal plants used by people in Oriental Morocco to manage various ailments," Journal of Ethnopharmacology, vol. 154, pp. 76-87, 2014.

[5] G. E. Holaly, K. D. Simplice, G. Charlemagne et al., "Étude ethnobotanique des plantes utilisées dans le traitement du diabète dans la médecine traditionnelle de la région Maritime du Togo," Pan African Medical Journal, vol. 20, pp. 1861-1868, 2015.

[6] H. N. Mrabti, N. Jaradat, M. R. Kachmar et al., "Integrative herbal treatments of diabetes in Beni Mellal region of Morocco," Journal of Integrative Medicine, vol. 17, no. 2, pp. 93-99, 2019.

[7] A. Bouyahya, J. Abrini, A. Et-touys, Y. Bakri, and N. Dakka, "Indigenous knowledge of the use of medicinal plants in the North-West of Morocco and their biological activities," European Journal of Integrative Medicine, vol. 13, pp. 9-25, 2017.

[8] M. El Haouari, S. El Makaoui, M. Jnah, and A. Haddaouy, "A survey of medicinal plants used by herbalists in Taza (Northern Morocco) to manage various ailments," Journal of Materials and Environmental Science, vol. 9, pp. 1875-1888, 2018.

[9] M. Hmamouchi, "Les plantes médicinales et aromatiques marocaines: Utilisation, biologie, écologie, chimie, pharmacologie, toxicologie, lexiques, IDPCM, mohammedia," 1999.

[10] M. Fennane, M. Ibn Tattou, and J. Mathez, "Practical flora of Morocco: Manual for the determination of vascular plants," Botanical Series, Institut Scientifique, Rabat, Morocco, 1999.

[11] J. Bellakhdar, "La pharmacopée marocaine traditionnelle, 2ème édition augmen," 1997, https://lefennec.com/livre/lapharmacopee-marocaine-traditionnelle-jamal-bellakhdar/.

[12] M. H. Yetein, L. G. Houessou, T. O. Lougbégnon, O. Teka, and B. Tente, "Ethnobotanical study of medicinal plants used for the treatment of malaria in plateau of Allada, Benin (West Africa)," Journal of Ethnopharmacology, vol. 146, no. 1, pp. 154-163, 2013.

[13] M. Maldonado-Garcia, C. Angulo, J. Vazquez-Martinez, V. Sanchez, M. G. Lopez, and M. Reyes-Becerril, "Antioxidant and immunostimulant potentials of Chenopodium ambrosioides L. in Pacific red snapper (Lutjanus peru)," Aquaculture, vol. 513, Article ID 734414, 2019.

[14] M. Reyes-Becerril, C. Angulo, V. Sanchez, J. VázquezMartínez, and M. G. López, "Antioxidant, intestinal immune status and anti-inflammatory potential of Chenopodium ambrosioides L. in fish: In vitro and in vivo studies," Fish \& Shellfish Immunology, vol. 86, pp. 420-428, 2019.

[15] C. Nencini, A. Menchiari, G. G. Franchi, and L. Micheli, "In vitro antioxidant activity of aged extracts of some Italian Allium species," Plant Foods for Human Nutrition, vol. 66, no. 1, pp. 11-16, 2011.

[16] E. Derwich, A. Manar, Z. Benziane, and A. Boukir, "GC/MS analysis and in vitro antibacterial activity of the essential oil isolated from leaf of Pistacia lentiscus growing in Morocoo," 
World Applied Sciences Journal, vol. 8, pp. 1267-1276, 2010, http://www.idosi.org/wasj/wasj8(10)/14.pdf.

[17] M. A. Dib, M. Bendahou, A. Bendiabdellah et al., "Partial chemical composition and antimicrobial activity of Daucus crinitus Desf. extracts," Grasas y Aceites, vol. 61, no. 3, pp. 271-278, 2010.

[18] S. Zougagh, A. Belghiti, T. Rochd et al., "Medicinal and aromatic plants used in traditional treatment of the oral pathology: the ethnobotanical survey in the economic capital casablanca, Morocco (North Africa)," Natural Products and Bioprospecting, vol. 9, no. 1, pp. 35-48, 2019.

[19] M. Abouri, A. El Mousadik, F. Msanda, H. Boubake, B. Saadi, and K. Cherifi, "An ethnobotanical survey of medicinal plants used in Rwanda for voluntary depigmentation," International Journal of Medicinal Plants Research, vol. 1, pp. 099-123, 2012.

[20] E.-M. Choi and J.-K. Hwang, "Antiinflammatory, analgesic and antioxidant activities of the fruit of Foeniculum vulgare," Fitoterapia, vol. 75, no. 6, pp. 557-565, 2004.

[21] P. Lo Cantore, N. S. Iacobellis, A. De Marco, F. Capasso, and F. Senatore, "Antibacterial activity of Coriandrum sativum L. and Foeniculum vulgare Miller var. vulgare (miller) essential oils," Journal of Agricultural and Food Chemistry, vol. 52, no. 26, pp. 7862-7866, 2004.

[22] İ. Gülçin, Ö. İ. Küfrevioǵlu, M. Oktay, and M. E. Büyükokuroǵlu, "Antioxidant, antimicrobial, antiulcer and analgesic activities of nettle (Urtica dioica L.)," Journal of Ethnopharmacology, vol. 90, no. 2-3, pp. 205-215, 2004.

[23] M. A. T. Abdel-Reheem and M. M. Oraby, "Anti-microbial, cytotoxicity, and necrotic ripostes of Pimpinella anisum essential oil," Annals of Agricultural Sciences, vol. 60, no. 2, pp. 335-340, 2015.

[24] M. Eddouks, M. Maghrani, A. Lemhadri, M.-L. Ouahidi, and H. Jouad, "Ethnopharmacological survey of medicinal plants used for the treatment of diabetes mellitus, hypertension and cardiac diseases in the south-east region of Morocco (Tafilalet)," Journal of Ethnopharmacology, vol. 82, no. 2-3, pp. 97-103, 2002.

[25] P. Wong and D. Kitts, "Studies on the dual antioxidant and antibacterial properties of parsley (Petroselinum crispum) and cilantro (Coriandrum sativum) extracts," Food Chemistry, vol. 97, no. 3, pp. 505-515, 2006.

[26] M. Ajebli and M. Eddouks, "Antihypertensive activity of Petroselinum crispum through inhibition of vascular calcium channels in rats," Journal of Ethnopharmacology, vol. 242, Article ID 112039, 2019.

[27] A. Abbaszadegan, A. Gholami, Y. Ghahramani et al., "Antimicrobial and cytotoxic activity of Cuminum cyminum as an intracanal medicament compared to chlorhexidine gel," Iranian Endodontic Journal, vol. 11, pp. 44-50, 2016.

[28] B. Deepa and C. V. Anuradha, "Antioxidant potential of Coriandrum sativum L. seed extract," Indian Journal of Experimental Biology, vol. 49, pp. 30-38, 2011.

[29] I. A. Al-Mofleh, A. A. Alhaider, J. S. Mossa, M. O. AlSohaibani, S. Rafatullah, and S. Qureshi, "Protection of gastric mucosal damage by Coriandrum sativum L. pretreatment in Wistar albino rats," Environmental Toxicology and Pharmacology, vol. 22, no. 1, pp. 64-69, 2006.

[30] N. Chaachouay, O. Benkhnigue, M. Fadli, R. El Ayadi, and L. Zidane, "Ethnobotanical study of medicinal plants used to treat osteoarticular diseases in the Moroccan Rif, Morocco," Journal of Pharmacy and Pharmacognosy Research, vol. 7, pp. 454-470, 2019.
[31] R. S. Suganya, K. Priya, and B. S. Roxy, "Phytochemical screening and antibacterial activity from nerium oleander and evaluvate their plant mediated nanoparticle synthesis," International Research Journal of Pharmacy, vol. 3, pp. 285-288, 2012.

[32] F. Ben Akka, S. Salhi, O. Benkhnigue, J. Dahmani, A. Douira, and L. Zidane, "Ethnobotanical study of medicinal plants used in the region of middle oum Rbia (Morocco)," Plant Archives, vol. 19, pp. 2005-2017, 2019.

[33] J. Hinou, C. Demetzos, C. Harvala, and C. Roussakis, "Cytotoxic and antimicrobial principles from the roots of Aristolochia longa," International Journal of Crude Drug Research, vol. 28, no. 2, pp. 149-151, 1990.

[34] N. El Omari, S. Akkaoui, O. El Blidi et al., "HPLC-DAD/ TOF-MS chemical compounds analysis and evaluation of antibacterial activity of Aristolochia longa root extracts," Natural Product Communications, vol. 15, pp. 0-5, 2020.

[35] M. Najem, H. Harouak, J. Ibijbijen, and L. Nassiri, "Oral disorders and ethnobotanical treatments: a field study in the central Middle Atlas (Morocco)," Heliyon, vol. 6, Article ID e04707, 2020.

[36] C. Alarcon De La Lastra, A. Lopez, and V. Motilva, "Gastroprotection and prostaglandin E2 generation in rats by flavonoids of Dittrichia viscosa," Planta Medica, vol. 59, pp. 497-501, 1993.

[37] W. Rhimi, I. Ben Salem, D. Immediato, M. Saidi, A. Boulila, and C. Cafarchia, "Chemical composition, antibacterial and antifungal activities of crude Dittrichia viscosa (L.) greuter leaf extracts," Molecules (Basel, Switzerland), vol. 22, pp. 113, 2017.

[38] N. Gharred, A. Dbeibia, D. Falconieri, S. Hammami, A. Piras, and S. Dridi-Dhaouadi, "Chemical composition, antibacterial and antioxidant activities of essential oils from flowers, leaves and aerial parts of Tunisian Dittrichia Viscosa," Journal of Essential Oil Research, vol. 31, no. 6, pp. 582-589, 2019.

[39] K. Bouabid, F. Lamchouri, H. Toufik, K. Sayah, Y. Cherrah, and M. E. A. Faouzi, "Phytochemical screening and in vitro evaluation of alpha amylase, alpha glucosidase and beta galactosidase inhibition by aqueous and organic Atractylis gummifera L. extracts," Plant Science Today, vol. 5, no. 3, pp. 103-112, 2018.

[40] E. Idm'Hand, F. Msanda, and K. Cherifi, "Ethnobotanical study and biodiversity of medicinal plants used in the Tarfaya province, Morocco," Shengtai Xuebao/Acta Ecologica Sinica, vol. 40, pp. 134-144, 2020.

[41] O. Sekiou, M. Boumendjel, F. Taibi, L. Tichati, A. Boumendjel, and M. Messarah, "Nephroprotective effect of Artemisia herba alba aqueous extract in alloxan-induced diabetic rats," Journal of Traditional and Complementary Medicine, vol. 11, no. 1, pp. 53-61, 2021.

[42] H. Mighri, H. Hajlaoui, A. Akrout, H. Najjaa, and M. Neffati, "Antimicrobial and antioxidant activities of Artemisia herbaalba essential oil cultivated in Tunisian arid zone," Comptes Rendus Chimie, vol. 13, no. 3, pp. 380-386, 2010.

[43] D. Khlifi, R. M. Sghaier, S. Amouri, D. Laouini, M. Hamdi, and J. Bouajila, "Composition and anti-oxidant, anti-cancer and anti-inflammatory activities of Artemisia herba-alba, Ruta chalpensis L. and Peganum harmala L," Food and Chemical Toxicology, vol. 55, pp. 202-208, 2013.

[44] H. Jaadan, M. Akodad, A. Moumen et al., "Ethnobotanical survey of medicinal plants growing in the region of "Oulad daoud zkhanine" (Nador province), in Northeastern 
Morocco," Ethnobotany Research and Applications, vol. 19, pp. 1-12, 2020.

[45] I. Karabegović, M. Nikolova, D. Veličković, S. Stojičević, V. Veljković, and M. Lazić, "Comparison of antioxidant and antimicrobial activities of methanolic extracts of the Artemisia sp. recovered by different extraction techniques," Chinese Journal of Chemical Engineering, vol. 19, pp. 504511, 2011.

[46] K. Mikou, S. Rachiq, and A. Jarrar Oulidi, "Étude ethnobotanique des plantes médicinales et aromatiques utilisées dans la ville de Fès au Maroc," Phytothérapie, vol. 14, no. 1, pp. 35-43, 2016.

[47] A. S. Braga, L. L. de M. Simas, J. G. Pires et al., "Antibiofilm and anti-caries effects of an experimental mouth rinse containing Matricaria chamomilla L. extract under microcosm biofilm on enamel," Journal of Dentistry, vol. 99, 2020.

[48] J. Kolodziejczyk-Czepas, M. Bijak, J. Saluk et al., "Radical scavenging and antioxidant effects of Matricaria chamomilla polyphenolic-polysaccharide conjugates," International Journal of Biological Macromolecules, vol. 72, pp. 1152-1158, 2015.

[49] A. Mollica, G. Zengin, M. Locatelli et al., "Anti-diabetic and anti-hyperlipidemic properties of Capparis spinosa L.: In vivo and in vitro evaluation of its nutraceutical potential," Journal of Functional Foods, vol. 35, pp. 32-42, 2017.

[50] J. Jiménez-López, A. Ruiz-Medina, P. Ortega-Barrales, and E. J. Llorent-Martínez, "Phytochemical profile and antioxidant activity of caper berries (Capparis spinosa L.): evaluation of the influence of the fermentation process," Food Chemistry, vol. 250, pp. 54-59, 2018.

[51] H. Boufous, F. Marhoume, A. Chait, and A. Bagri, "Ethnopharmacological survey of medicinal plants with hallucinogenic effect and plants used against pain, inflammatory diseases, diabetes and urinary lithiasis in Zagora "Morocco"” Journal of Intercultural Ethnopharmacology, vol. 6, no. 4, pp. 342-350, 2017.

[52] M. El Midaoui, A. Maataoui, M. Benbella, A. Ait Houssa, and N. Labazi, "Ethnobotanical study of some aromatic and medicinal plants in the Middle Atlas Mountains of Morocco," Natural Product Communications, vol. 6, pp. 14551458, 2011.

[53] F. Atmani, Y. Slimani, M. Mimouni, M. Aziz, B. Hacht, and A. Ziyyat, "Effect of aqueous extract from Herniaria hirsuta L. on experimentally nephrolithiasic rats," Journal of Ethnopharmacology, vol. 95, no. 1, pp. 87-93, 2004.

[54] A. Merzouki, F. Ed-derfoufi, and J. Molero Mesa, "Contribution to the knowledge of Rifian traditional medicine II: Folk medicine in Ksar Lakbir district (NW Morocco)," Fitoterapia, vol. 71, no. 3, pp. 278-307, 2000.

[55] M. El Kabbaoui, A. Chda, O. Azdad et al., "Evaluation of hypoglycemic and hypolipidemic activities of aqueous extract of Cistus ladaniferus in streptozotocin-induced diabetic rats," Asian Pacific Journal of Tropical Biomedicine, vol. 6, no. 12, pp. 1044-1049, 2016.

[56] T. Benali, A. Bouyahya, K. Habbadi et al., "Chemical composition and antibacterial activity of the essential oil and extracts of Cistus ladaniferus subsp. ladanifer and Mentha suaveolens against phytopathogenic bacteria and their ecofriendly management of phytopathogenic bacteria," Biocatalysis and Agricultural Biotechnology, vol. 28, Article ID 101696, 2020.

[57] A. Youbi, I. Ouahidi, L. Mansouri, A. Daoudi, and D. Bousta, "Ethnopharmacological survey of plants used for immunological diseases in four regions of Morocco," European Journal of Medicinal Plants, vol. 13, no. 1, pp. 1-24, 2016.

[58] E. Derwich, Z. Benziane, and A. Boukir, "Chemical composition of leaf essential oil of juniperus phoenicea and evaluation of its antibacterial activity," International Journal of Agriculture and Biology, vol. 12, pp. 199-204, 2010.

[59] I. Teixidor-Toneu, G. J. Martin, A. Ouhammou, R. K. Puri, and J. A. Hawkins, "An ethnomedicinal survey of a Tashelhitspeaking community in the High Atlas, Morocco," Journal of Ethnopharmacology, vol. 188, pp. 96-110, 2016.

[60] W. Rached, F. Z. Zeghada, M. Bennaceur et al., "Phytochemical analysis and assessment of antioxidant, antimicrobial, anti-inflammatory and cytotoxic properties of Tetraclinis articulata (Vahl) Masters leaves," Industrial Crops and Products, vol. 112, pp. 460-466, 2018.

[61] M. Achmit, N. Aoussar, F. Mellouki et al., "In vitro antibacterial and biofilm inhibitory activity of the sawdust essential oil of Tetraclinis articulata (vahl) against catheterassociated Staphylococcus aureus clinical isolates," Current Research in Biotechnology, vol. 3, pp. 1-5, 2021.

[62] R. H. Elkousy, Z. N. A. Said, M. A. Abd El-Baseer, and S. A. Abu El wafa, "Antiviral activity of castor oil plant (Ricinus communis) leaf extracts," Journal of Ethnopharmacology, vol. 271, Article ID 113878, 2021.

[63] S. Subhapriya and P. Gomathipriya, "Green synthesis of titanium dioxide $\left(\mathrm{TiO}_{2}\right)$ nanoparticles by Trigonella foenumgraecum extract and its antimicrobial properties," Microbial Pathogenesis, vol. 116, pp. 215-220, 2018.

[64] M. Cheurfa, R. Allem, N. B. Sadeer, and M. F. Mahomoodally, "In vivo hypocholesterolemic and anti-inflammatory effect of Aloysia triphylla (L'Hér.) Britton and Trigonella foenum-groecum L. seeds," South African Journal of Botany, 2021, In press.

[65] M.-J. Bae, H. S. Shin, D.-W. Choi, and D.-H. Shon, "Antiallergic effect of Trigonella foenum-graecum L. extracts on allergic skin inflammation induced by trimellitic anhydride in BALB/c mice," Journal of Ethnopharmacology, vol. 144, no. 3, pp. 514-522, 2012.

[66] M. R. Kachmar, A. P. Oliveira, P. Valentão et al., "HPLC$\mathrm{DAD}-\mathrm{ESI} / \mathrm{MS}^{\mathrm{n}}$ phenolic profile and in vitro biological potential of Centaurium erythraea Rafn aqueous extract," Food Chem.vol. 278, 2019.

[67] L. Mansar-benhamza, Z. Djerrou, and Y. Hamdi Pacha, "Evaluation of anti-hyperglycemic activity and side effects of Erythraea centaurium (L.) Pers. in rats," African Journal of Biotechnology, vol. 12, pp. 6980-6985, 2013.

[68] M. Haloui, L. Louedec, J.-B. Michel, and B. Lyoussi, "Experimental diuretic effects of Rosmarinus officinalis and Centaurium erythraea," Journal of Ethnopharmacology, vol. 71, no. 3, pp. 465-472, 2000.

[69] O. Yumrutas and S. D. Saygideger, "Determination of antioxidant and antimutagenic activities of Phlomis armeniaca and Mentha pulegium," Journal of Applied Pharmaceutical Science, vol. 2, pp. 36-40, 2012.

[70] S. Bouhdid, S. N. Skali, M. Idaomar et al., "Antibacterial and antioxidant activities of Origanum compactum essential oil," African Journal of Biotechnology, vol. 7, pp. 1563-1570, 2008.

[71] W. Chaouki, D. Y. Leger, J. Eljastimi, J.-L. Beneytout, and M. Hmamouchi, "Antiproliferative effect of extracts from Aristolochia baetica and Origanum compactumon human breast cancer cell line MCF-7," Pharmaceutical Biology, vol. 48, no. 3, pp. 269-274, 2010. 
[72] N. Mezzoug, A. Elhadri, A. Dallouh et al., "Investigation of the mutagenic and antimutagenic effects of Origanum compactum essential oil and some of its constituents," Mutation Research/Genetic Toxicology and Environmental Mutagenesis, vol. 629, no. 2, pp. 100-110, 2007.

[73] H. Mechachate, I. Es-safi, F. Jawhari, A. Bari, A. Grafov, and D. Bousta, "Ethnobotanical survey about the management of diabetes with medicinal plants used by diabetic patients in Region of Fez-Meknès Morocco," Ethnobotany Research and Applications, vol. 19, pp. 1-28, 2020.

[74] M. Hayani, N. Benhlima, A. Bouzoubaa et al., "Phytochemical study, polyphenols determination and evaluation of antioxidant activity of Origanum compactum and Satureja calamintha nepeta from the region of Ouazzane (Morocco)," Mediterranean Journal of Chemistry, vol. 10, no. 4, p. 396, 2020.

[75] L. Cherrat, L. Espina, M. Bakkali, R. Pagán, and A. Laglaoui, "Chemical composition, antioxidant and antimicrobial properties of Mentha pulegium, Lavandula stoechas and Satureja calamintha Scheele essential oils and an evaluation of their bactericidal effect in combined processes," Innovative Food Science \& Emerging Technologies, vol. 22, pp. 221-229, 2014.

[76] N. Akther, A. S. Shawl, S. Sultana, B. K. Chandan, and M. Akhter, "Hepatoprotective activity of Marrubium vulgare against paracetamol induced toxicity," Journal of Pharmacy Research, vol. 7, no. 7, pp. 565-570, 2013.

[77] M. Rezgui, N. Majdoub, B. Mabrouk et al., "Antioxidant and antifungal activities of marrubiin, extracts and essential oil from Marrubium vulgare L. against pathogenic dermatophyte strains," Journal de Mycologie Médicale, vol. 30, no. 1, Article ID 100927, 2020.

[78] F. Z. El Hassani, "Characterization, activities, and ethnobotanical uses of Mentha species in Morocco," Heliyon, vol. 6, no. 11, Article ID e05480, 2020.

[79] L. Boussouf, H. Boutennoune, M. Kebieche, N. Adjeroud, K. Al-Qaoud, and K. Madani, "Anti-inflammatory, analgesic and antioxidant effects of phenolic compound from Algerian Mentha rotundifolia L. leaves on experimental animals," South African Journal of Botany, vol. 113, pp. 77-83, 2017.

[80] G. Yakhlef, L. Hambaba, D. C. G. A. Pinto, and A. M. S. Silva, "Chemical composition and insecticidal, repellent and antifungal activities of essential oil of Mentha rotundifolia (L.) from Algeria," Industrial Crops and Products, vol. 158, Article ID 112988, 2020.

[81] A. Bouyahya, J. Abrini, A. El-baabou, Y. Bakri, and N. Dakka, "Determination of phenol content and antibacterial activity of five medicinal plants ethanolic extracts from North-west of Morocco," Journal of Plant Pathology and Microbiology, vol. 07, 2016.

[82] J. E. Hilaly and B. Lyoussi, "Hypoglycaemic effect of the lyophilised aqueous extract of Ajuga iva in normal and streptozotocin diabetic rats," Journal of Ethnopharmacology, vol. 80, no. 2-3, pp. 109-113, 2002.

[83] J. El-Hilaly, A. Tahraoui, Z. H. Israili, and B. Lyoussi, "Acute hypoglycemic, hypocholesterolemic and hypotriglyceridemic effects of continuous intravenous infusion of a lyophilised aqueous extract of Ajuga iva L. Schreber whole plant in streptozotocin-induced diabetic rats," Pakistan Journal of Pharmaceutical Sciences, vol. 20, pp. 261-268, 2007.

[84] A. Talbaoui, "Chemical composition and antibacterial activity of essential oils from six Moroccan plants," Journal of Medicinal Plant Research, vol. 6, 2012.
[85] H. Ouhaddou, H. Boubaker, F. Msanda, and A. El Mousadik, "An ethnobotanical study of medicinal plants of the Agadir Ida Ou Tanane province (Southwest Morocco)," Journal of Applied Biosciences, vol. 84, no. 1, p. 7707, 2015.

[86] A. Et-Touys, H. Fellah, M. Mniouil et al., "Screening of antioxidant, antibacterial and antileishmanial activities of Salvia officinalis L. Extracts from Morocco," British Microbiology Research Journal, vol. 16, no. 5, pp. 1-10, 2016.

[87] Z. Nadia and M. Rachid, "Antioxidant and antibacterial activities of thymus vulgaris," Medicinal and Aromatic Plants Research Journals, vol. 1, pp. 5-11, 2013.

[88] R. Chizzola, H. Michitsch, and C. Franz, "Antioxidative properties of Thymus vulgaris leaves: Comparison of different extracts and essential oil chemotypes," Journal of Agricultural and Food Chemistry, vol. 56, no. 16, pp. 68976904, 2008.

[89] N. Chaachouay, O. Benkhnigue, and L. Zidane, "Ethnobotanical study aimed at investigating the use of medicinal plants to treat nervous System diseases in the Rif of Morocco," Journal of Chiropractic Medicine, vol. 19, no. 1, pp. 70-81, 2020.

[90] H. Boukhebti, A. N. Chaker, H. Belhadj et al., "Chemical composition and antibacterial activity of Mentha pulegium L. and Mentha spicata L. essential oils," Der Pharmacia Lettre, vol. 3, pp. 267-275, 2011.

[91] S. R. Kanatt, R. Chander, and A. Sharma, "Antioxidant potential of mint (Mentha spicata L.) in radiation-processed lamb meat," Food Chemistry, vol. 100, no. 2, pp. 451-458, 2007.

[92] S. Abbasi-Maleki, Z. Kadkhoda, and R. Taghizad-Farid, "The antidepressant-like effects of Origanum majorana essential oil on mice through monoaminergic modulation using the forced swimming test," Journal of Traditional and Complementary Medicine, vol. 10, no. 4, pp. 327-335, 2020.

[93] H. Hajlaoui, H. Mighri, M. Aouni, N. Gharsallah, and A. Kadri, "Chemical composition and in vitro evaluation of antioxidant, antimicrobial, cytotoxicity and anti-acetylcholinesterase properties of Tunisian Origanum majorana L. essential oil," Microbial Pathogenesis, vol. 95, pp. 86-94, 2016.

[94] J. Bellakhdar, R. Claisse, J. Fleurentin, and C. Younos, "Repertory of standard herbal drugs in the Moroccan pharmacopoea," Journal of Ethnopharmacology, vol. 35, no. 2, pp. 123-143, 1991.

[95] F. U. Afifi, E. Khalil, S. O. Tamimi, and A. Disi, "Evaluation of the gastroprotective effect of Laurus nobilis seeds on ethanol induced gastric ulcer in rats," Journal of Ethnopharmacology, vol. 58, no. 1, pp. 9-14, 1997.

[96] A. Merghni, H. Marzouki, H. Hentati, M. Aouni, and M. Mastouri, "Antibacterial and antibiofilm activities of Laurus nobilis L. essential oil against Staphylococcus aureus strains associated with oral infections," Current Research in Translational Medicine, vol. 64, no. 1, pp. 29-34, 2016.

[97] O. Choi, S. K. Cho, J. Kim, C. G. Park, and J. Kim, "In vitro antibacterial activity and major bioactive components of Cinnamomum verum essential oils against cariogenic bacteria, Streptococcus mutans and Streptococcus sobrinus," Asian Pacific Journal of Tropical Biomedicine, vol. 6, no. 4, pp. 308-314, 2016.

[98] P. M. Mariappan, G. Sabesan, B. Koilpillai, S. Janakiraman, and N. K. Sharma, "Chemical characterisation and antifungal activity of methanolic extract of Cinnamomum verum J. Presl bark against Malassezia spp," Pharmacognosy Journal, vol. 5, no. 5, pp. 197-204, 2013. 
[99] M. Yusuf, A. Ahmad, M. Shahid et al., "Assessment of colorimetric, antibacterial and antifungal properties of woollen yarn dyed with the extract of the leaves of henna (Lawsonia inermis)," Journal of Cleaner Production, vol. 27, pp. 42-50, 2012.

[100] M. Jridi, S. Sellimi, K. B. Lassoued et al., "Wound healing activity of cuttlefish gelatin gels and films enriched by henna (Lawsonia inermis) extract," Colloids and Surfaces A: Physicochemical and Engineering Aspects, vol. 512, pp. 71-79, 2017.

[101] E. C. Jeyaseelan, S. Jenothiny, M. Pathmanathan, and J. Jeyadevan, "Antibacterial activity of sequentially extracted organic solvent extracts of fruits, flowers and leaves of Lawsonia inermis L. from Jaffna," Asian Pacific Journal of Tropical Biomedicine, vol. 2, no. 10, pp. 798-802, 2012.

[102] F. Mousa, A. Ali, M. Nasir, and K. Khattak, "Comparative anticancer activities of Ficus carica and Ficus salicifolia latex in MDA-MB-231 cells," Saudi Journal of Biological Sciences, vol. $28,2021$.

[103] D. Fouad, H. Alhatem, R. Abdel-Gaber, and F. Ataya, "Hepatotoxicity and renal toxicity induced by gamma-radiation and the modulatory protective effect of Ficus carica in male albino rats," Research in Veterinary Science, vol. 125, pp. 24-35, 2019.

[104] R. G. Bachir and M. Benali, "Antibacterial activity of the essential oils from the leaves of Eucalyptus globulus against Escherichia coli and Staphylococcus aureus," Asian Pacific Journal of Tropical Biomedicine, vol. 2, no. 9, pp. 739-742, 2012.

[105] H. Jouad, A. Lemhadri, M. Maghrani, R. Burcelin, and M. Eddouks, "Hawthorn evokes a potent anti-hyperglycemic capacity in streptozotocin-induced diabetic rats," Journal of Herbal Pharmacotherapy, vol. 3, no. 2, pp. 19-29, 2003.

[106] M. Amensour, E. Sendra, J. Abrini, S. Bouhdid, J. A. PérezAlvarez, and J. Fernández-López, "Total phenolic content and antioxidant activity of myrtle (Myrtus communis) extracts," Natural Product Communications, vol. 4, no. 6, pp. 819-824, 2009.

[107] N. Hayder, A. Abdelwahed, S. Kilani et al., "Anti-genotoxic and free-radical scavenging activities of extracts from (Tunisian) Myrtus communis," Mutation Research/Genetic Toxicology and Environmental Mutagenesis, vol. 564, no. 1, pp. 89-95, 2004.

[108] A. Sepici, I. Gürbüz, C. Çevik, and E. Yesilada, "Hypoglycaemic effects of myrtle oil in normal and alloxan-diabetic rabbits," Journal of Ethnopharmacology, vol. 93, no. 2-3, pp. 311-318, 2004.

[109] S. El amrani, A. El Ouali Lalami, Y. Ez zoubi, K. Moukhafi, R. Bouslamti, and S. Lairini, "Evaluation of antibacterial and antioxidant effects of cinnamon and clove essential oils from Madagascar," Materials Today: Proceedings, vol. 13, pp. 762-770, 2019.

[110] P. L. B. Figueiredo, L. C. Pinto, J. S. da Costa et al., "Composition, antioxidant capacity and cytotoxic activity of Eugenia uniflora L. chemotype-oils from the Amazon," Journal of Ethnopharmacology, vol. 232, pp. 30-38, 2019.

[111] M.-T. Moradi, A. Karimi, M. Rafieian-Kopaei, and F. Fotouhi, "In vitro antiviral effects of Peganum harmala seed extract and its total alkaloids against Influenza virus," Microbial Pathogenesis, vol. 110, pp. 42-49, 2017.

[112] G. Nenaah, "Antibacterial and antifungal activities of (beta)carboline alkaloids of Peganum harmala (L) seeds and their combination effects," Fitoterapia, vol. 81, no. 7, pp. 779-782, 2010 .
[113] I. Hazarika, M. Hussain, and A. Das, "Anti-Ulcer activity of ethanolic extract of Sesamum indicum seed on indomethacin-induced ulcer model and its antioxidant property in Gastro-protection," Research \& Reviews: A Journal of Pharmacology, vol. 5, pp. 18-25, 2015.

[114] C. N. Okwuosa, R. Okoi-Ewa, P. U. Achukwu, A. C. Onuba, and N. C. Azubuike, "Gastro-protective effect of crude hexane leaf extract of Sesamum indicum in rabbits," Nigerian Journal of Physiological Sciences, vol. 26, pp. 49-54, 2011.

[115] A. Ruckmani, V. Meti, R. Vijayashree et al., "Anti-rheumatoid activity of ethanolic extract of Sesamum indicum seed extract in Freund's complete adjuvant induced arthritis in Wistar albino rats," Journal of Traditional and Complementary Medicine, vol. 8, no. 3, pp. 377-386, 2018.

[116] Z. Farooqui, F. Ahmed, S. Rizwan, F. Shahid, A. A. Khan, and F. Khan, "Protective effect of Nigella sativa oil on cisplatin induced nephrotoxicity and oxidative damage in rat kidney," Biomedicine \& Pharmacotherapy, vol. 85, pp. 7-15, 2017.

[117] G. Rathi, S. I. Siddiqui, Q. Pham, and V. T. Nam, "Nigella sativa seeds based antibacterial composites: a sustainable technology for water cleansing-a review," Sustainable Chemistry and Pharmacy, vol. 18, Article ID 100332, 2020.

[118] F. Dahlia, S. Barouagui, H. Hemida, D. Bousaadia, and B. Rahmoune, "Influence of environment variations on antiglycaemic, anti-cholesterolemic, antioxidant and antimicrobial activities of natural wild fruits of Ziziphus lotus (L.)," South African Journal of Botany, vol. 132, pp. 215-225, 2020.

[119] H. Harizi, F. Chaabane, K. Ghedira, and L. Chekir-Ghedira, "Inhibition of proinflammatory macrophage responses and lymphocyte proliferation in vitro by ethyl acetate leaf extract from Daphne gnidium," Cellular Immunology, vol. 267, no. 2, pp. 94-101, 2011.

[120] F. Cottigli, G. Loy, D. Garau et al., "Antimicrobial evaluation of coumarins and flavonoids from the stems of L," Phytomedicine, vol. 8, no. 4, pp. 302-305, 2001.

[121] N. A. Salih, "Antibacterial effect of nettle (Urtica dioica)," AlQadisiyah Journal of Veterinary Medicine Sciences, vol. 13, no. 1, p. 1, 2014.

[122] S. M. B. Hashemi, A. Mousavi Khaneghah, M. Koubaa et al., "Extraction of essential oil from Aloysia citriodora Palau leaves using continuous and pulsed ultrasound: Kinetics, antioxidant activity and antimicrobial properties," Process Biochemistry, vol. 65, pp. 197-204, 2018.

[123] I. Alami Merrouni and M. Elachouri, "Anticancer medicinal plants used by Moroccan people: ethnobotanical, preclinical, phytochemical and clinical evidence," Journal of Ethnopharmacology, vol. 266, Article ID 113435, 2021.

[124] S. Naz, S. Jabeen, S. Ilyas, F. Manzoor, F. Aslam, and A. Ali, "Antibacterial activity of Curcuma longa varieties against different strains of bacteria," Pakistan Journal of Botany, vol. 42, pp. 455-462, 2010.

[125] R. S. Ramsewak, D. L. DeWitt, and M. G. Nair, "Cytotoxicity, antioxidant and anti-inflammatory activities of curcumins I-III from Curcuma longa," Phytomedicine, vol. 7, no. 4, pp. 303-308, 2000.

[126] I. Stoilova, A. Krastanov, A. Stoyanova, P. Denev, and S. Gargova, "Antioxidant activity of a ginger extract (Zingiber officinale)," Food Chemistry, vol. 102, no. 3, pp. 764-770, 2007.

[127] S. Malu, G. Obochi, E. Tawo, and B. Nyong, "Antibacterial activity and medicinal properties of ginger (Zingiber officinale)," Global Journal of Pure and Applied Sciences, vol. 15, pp. 365-368, 2009. 
[128] N. Chaachouay, O. Benkhnigue, M. Fadli, H. El Ibaoui, and L. Zidane, "Ethnobotanical and ethnopharmacological studies of medicinal and aromatic plants used in the treatment of metabolic diseases in the Moroccan Rif," Heliyon, vol. 5, no. 10, Article ID e02191, 2019.

[129] C. Anyinam, "Ecology and ethnomedicine: exploring links between current environmental crisis and indigenous medical practices," Social Science \& Medicine, vol. 40, no. 3, pp. 321-329, 1995.

[130] A. Daoudi, M. Bammou, S. Zarkani, I. Slimani, J. Ibijbijen, and L. Nassiri, "Étude ethnobotanique de la flore médicinale dans la commune rurale d'Aguelmouss province de Khénifra (Maroc)," Phytothérapie, vol. 14, no. 4, pp. 220-228, 2015.

[131] M. D. Miara, H. Bendif, K. Rebbas, B. Rabah, M. A. Hammou, and F. Maggi, "Medicinal plants and their traditional uses in the highland region of Bordj Bou Arreridj (Northeast Algeria)," Journal of Herbal Medicine, vol. 16, Article ID 100262, 2019.

[132] S. M. Wassie, L. L. Aragie, B. W. Taye, and L. B. Mekonnen, "Knowledge, attitude, and utilization of traditional medicine among the communities of Merawi town, northwest Ethiopia: a cross-Sectional study," Evidence-Based Complementary and Alternative Medicine, vol. 2015, Article ID 138073, 2015.

[133] N. Chaachouay, O. Benkhnigue, M. Fadli, H. El Ibaoui, R. El Ayadi, and L. Zidane, "Ethnobotanical and ethnopharmacological study of medicinal and aromatic plants used in the treatment of respiratory System disorders in the Moroccan Rif," Ethnobotany Research and Applications, vol. 18, 2019.

[134] F. M. El-mokasabi, M. F. Al-sanousi, and R. M. El-mabrouk, "Taxonomy and ethnobotany of medicinal plants in eastern region of Libya," Journal of Environmental Science, Toxicology and Food Technology, vol. 12, pp. 14-23, 2018.

[135] A. Chahbi, S. Nassik, H. El Amri et al., "Chemical composition and antimicrobial activity of the essential oils of two aromatic plants cultivated in Morocco (Cinnamomum cassia and Origanum compactum)," Journal of Chemistry, vol. 2020, Article ID 1628710, 2020.

[136] A. R. Wani, K. Yadav, A. Khursheed, and M. A. Rather, "An updated and comprehensive review of the antiviral potential of essential oils and their chemical constituents with special focus on their mechanism of action against various influenza and coronaviruses," Microbial Pathogenesis, vol. 2020, Article ID 104620, 2020.

[137] A. E. Karadağ, B. Demirci, A. Çaşkurlu et al., "In vitro antibacterial, antioxidant, anti-inflammatory and analgesic evaluation of Rosmarinus officinalis L. flower extract fractions," South African Journal of Botany, vol. 125, pp. 214-220, 2019.

[138] B. P. Murino Rafacho, P. P. Dos Santos, A. D. F. Gonçalves et al., "Rosemary supplementation (Rosmarinus oficinallis L.) attenuates cardiac remodeling after myocardial infarction in rats," PLoS One, vol. 12, pp. 1-17, 2017.

[139] M. A. Oukerrou, M. Tilaoui, H. A. Mouse, I. Leouifoudi, A. Jaafari, and A. Zyad, "Chemical composition and cytotoxic and antibacterial activities of the essential oil of Aloysia citriodora Palau Grown in Morocco," Advances in Pharmacological Sciences, vol. 2017, Article ID 7801924, 2017.

[140] A. Bertella, K. Benlahcen, S. Abouamama et al., “Artemisia herba-alba Asso. essential oil antibacterial activity and acute toxicity," Industrial Crops and Products, vol. 116, pp. 137143, 2018.
[141] K. Gharzouli, S. Khennouf, S. Amira, and A. Gharzouli, "Effects of aqueous extracts from Quercus ilex 1. root bark, Punica granatum 1. fruit peel and Artemisia herba-alba Asso leaves on ethanol-induced gastric damage in rats," Phytotherapy Research, vol. 13, no. 1, pp. 42-45, 1999.

[142] M. D. Miara, H. Bendif, M. Ait Hammou, and I. TeixidorToneu, "Ethnobotanical survey of medicinal plants used by nomadic peoples in the Algerian steppe," Journal of Ethnopharmacology, vol. 219, pp. 248-256, 2018.

[143] F. Tra Bi, G. Irie, K. N'Gaman, and C. Mahou, "Études de quelques plantes thérapeutiques utilisées dans le traitement de l|'hypertension artérielle et du diabète: Deux maladies émergentes en Côte dl'Ivoire," Science of Nature, vol. 5, pp. 39-48, 2008. 